\title{
BMJ Open Short-term outcomes and mortality after interhospital intensive care transportation: an observational prospective cohort study of 368 consecutive transports with a mobile intensive care unit
}

\author{
Ulrich Strauch, ${ }^{1}$ Dennis C J J Bergmans, ${ }^{1}$ Bjorn Winkens, ${ }^{2}$ Paul M H J Roekaerts ${ }^{1}$
}

To cite: Strauch U, Bergmans DCJJ, Winkens B, et al. Short-term outcomes and mortality after interhospital intensive care transportation: an observational prospective cohort study of 368 consecutive transports with a mobile intensive care unit. BMJ Open 2015;5:e006801. doi:10.1136/bmjopen-2014006801

- Prepublication history for this paper is available online. To view these files please visit the journal online (http://dx.doi.org/10.1136/ bmjopen-2014-006801).

Received 14 October 2014 Revised 8 March 2015 Accepted 12 March 2015

CrossMark

\footnotetext{
${ }^{1}$ Department of Intensive Care Medicine, Maastricht University Medical Centre, Maastricht, The Netherlands ${ }^{2}$ Department of Methodology and Statistics, Maastricht University, Maastricht, The Netherlands
}

Correspondence to Ulrich Strauch; u.strauch@mumc.nl

\section{ABSTRACT}

Objectives: To evaluate short-term outcomes and mortality after interhospital transportation of intensive care patients performed by a mobile intensive care unit (MICU).

Setting: This study was performed in the tertiary care process of interhospital transportation using the local MICU system in the South East of the Netherlands.

Participants: Between March 2009 and December 2011, all transports of adult patients being performed by the local MICU centre have been documented; data on 42 variables, including a $24 \mathrm{~h}$ follow-up Sequential Organ Failure Assessment (SOFA) score of 368 consecutive interhospital transports of intensive care patients, were recorded. In 24 cases, the follow-up SOFA score was missing, so 344 data sets were included.

Interventions: No interventions have been done. Primary/secondary outcome measures: Primary outcome measures were the mean SOFA score before and $24 \mathrm{~h}$ after transport, and the $24 \mathrm{~h}$ post-transport mortality. Moreover, the differences between the groups of $24 \mathrm{~h}$ post-transport survivors and non-survivors have been analysed.

Results: The mean SOFA score before transport was 8.8 for the whole population and 8.6 for those patients who were alive $24 \mathrm{~h}$ after transport, with a mean SOFA score of 8.4 after transport. The adverse events rate was $6.4 \%$. Fourteen patients (4.1\%) died within $24 \mathrm{~h}$ after transport. Patients in this group had a higher SOFA score, lower $\mathrm{pH}$, higher age and more additional medical support devices than those patients in the survivor group.

Conclusions: The non-significant decrease in the posttransport SOFA score and the lack of an association between transport and $24 \mathrm{~h}$ post-transport mortality indicates that in the study setting, interhospital transportation of intensive care patients performed by a MICU system was not associated with a clinically relevant deterioration of the patient.

\section{INTRODUCTION}

Transport of critically ill patients is known to be a high-risk procedure with a significant

\section{Strengths and limitations of this study}

With our study, we generated relevant and new outcome data on critically ill patients who underwent interhospital transportation by comparing the Sequential Organ Failure Assessment (SOFA) score on the day of transport with the $24 \mathrm{~h}$ posttransport SOFA score.

- We briefly analyse all cases of $24 \mathrm{~h}$ posttransport mortality.

- This study is a descriptive analysis of a singlecentre database with a limited number of patients and with only one post-transport data set (SOFA score) $24 \mathrm{~h}$ after mobile intensive care unit transport.

- Owing to the single-centre characteristic of the study, selection bias cannot be ruled out.

rate of adverse events; nearly $68 \%$ of serious adverse events have been documented in up to $89 \%$ of intrahospital transports. ${ }^{1}$ The adequate provision of qualified and experienced staff along with specially designed and well-maintained equipment are found to be protective, ${ }^{2-5}$ especially since during the interhospital transportation, the patients' safety can be compromised due to the absence of qualified medical staff and the lack of adequate resuscitation equipment. ${ }^{6-10}$ In a report of the Dutch healthcare authority 'Inspectie voor de Gezondheidszorg' from 2005, the authors concluded that interhospital transports in the Netherlands were often performed with inadequately staffed and underutilised transport facilities. ${ }^{11}$ Therefore, the Dutch government by law assigned seven tertiary hospitals to carry out interhospital transports of critically ill adult patients by a mobile intensive care unit (MICU) daily, from 07:00 until 23:00. Patients in need of an immediate life-saving intervention in an expertise centre were beyond the scope of MICU transportation. ${ }^{12}$ 
A MICU generally consists of a high-volume ambulance, a special trolley with all monitoring, resuscitation and treatment equipment fixed to it and a dedicated retrieval team, including an ambulance driver (from the local emergency medical service), an intensive care nurse and an intensive care physician (both from the local tertiary intensive care unit (ICU)). All clinical team members are trained in the local simulation centre before performing the first transport and the first couple of transports are under direct supervision of an experienced colleague.

Debriefing takes place routinely; all critical events that occurred during transport have been discussed with the medical coordinator and have been registered nationally. Furthermore, there is a 1-day simulator-based follow-up training for all clinical MICU team members once a year.

The Sequential Organ Failure Assessment (SOFA) score is an established, good validated intensive care score which is used to describe worsening or improvement in the patient's condition and has a good correlation with mortality, with a higher score indicating worse outcome. ${ }^{13}$ For all transports, the SOFA scores have been calculated at the day of transport and $24 \mathrm{~h}$ after transport. In this paper, changes in these two SOFA scores are used to describe short-term outcome. Moreover, regarding the patients who died within the first $24 \mathrm{~h}$ after transport, we performed further analysis to determine if there were transport-related effects on the $24 \mathrm{~h}$ post-transport mortality.

\section{OBJECTIVES}

To evaluate short-term ( $24 \mathrm{~h}$ after transport) outcome and mortality after interhospital transports of intensive care patients in the South East of the Netherlands.

\section{MATERIALS AND METHODS}

All transports performed by the MICU Maastricht between March 2009 and December 2011 were prospectively documented. All relevant data were obtained from the patient charts and transferred into a dedicated database by a data manager of the ICU department. All interhospital transports concerned adult intensive care patients in the southeast region of the Netherlands. Forty-two items were scored, including patient demographics; diagnosis; SOFA score pretransportation and post-transportation; use of vasoactive medications; ventilator settings; transportrelated factors such as transport time, transport team members; additional medical devices such as extracorporeal membrane oxygenation (ECMO) or intra-aortic balloon counter pulsation (IABP); and critical events. Critical events were registered following national definitions with technical (eg, ambulance, trolley, equipmentrelated) and non-technical events (eg, drop in oxygen saturation by more than $10 \%$ or drop in mean arterial pressure by more than $20 \mathrm{~mm} \mathrm{Hg}$ for at least $10 \mathrm{~min}$ ). The MICU nurse called the receiving ICU $24 \mathrm{~h}$ after the transport to obtain information about the patient's status (deceased or if alive actual SOFA score).Only transports with complete data sets, including a pretransport and a post-transport SOFA score, were analysed. All transports were performed and documented by a specialised retrieval team. In 24 from the 368 cases, the follow-up SOFA score was missing; so 344 data sets were included for analysis.

Numerical variables are presented by mean (SD) or median (range) if the data are clearly not normally distributed based on histograms. For categorical variables, frequency $(\%)$ is given. Differences in numerical variables between patients who died versus patients who did not die within $24 \mathrm{~h}$ after transport were analysed using independent samples $\mathrm{t}$ tests or Mann-Whitney $\mathrm{U}$ tests, wherever appropriate. $\chi^{2}$ or Fisher's exact test was used for categorical variables. All analyses were performed using the Statistical Package for the Social Sciences (V.20.0, SPSS Inc, Chicago, Illinois, USA).

A two-sided $\mathrm{p}$ value $\leq 0.05$ was considered statistically significant.

\section{RESULTS}

\section{Patient characteristics}

A total of 368 transports were performed from March 2009 until December 2011, from which 344 data sets were complete. A broad range of patients, in terms of severity of illness (mean SOFA score 8.8, range 0-20), were transported, including 15 patients on ECMO. Nearly all patients were mechanically ventilated and the majority of the patients were in need of a higher level ICU or for advanced treatment options, for example, heart transplantation or treatment in a burn unit. The median days of admission before transport was 4 , reflecting the fact that urgent transports were not performed with the MICU system. Additional medical devices as ECMO, nitric oxide (NO) or IABP, indicating severe illness, were present in $6.4 \%$ of the transports.

In the subgroup of patients transported with venovenous ECMO, all devices have been placed off centre by the transport team supported by a perfusionist from the local tertiary centre. The data of this subgroup are separately described in the tables 1 and 2.

\section{Transport characteristics and outcome parameters}

There is a non-significant decrease in SOFA score after transport ( 8.6 vs $8.4, p=0.174$ ) for the group to be alive $24 \mathrm{~h}$ after transport $(\mathrm{n}=330)$. In total, there were 22 critical events reported with 2 severe events needing immediate interventions (spontaneous ventricular tachycardia, disconnection of hub from ECMO tubing system). The majority of events were technical problems, for example, with the power supply of the ambulance or one of the medical devices. None of the latter problems affected the patient's safety because the transport trolley has a stand-alone time from $2 \mathrm{~h}$ and back-up devices for ventilation, monitoring and resuscitation can be found in the ambulance. 
Table 1 Patient characteristics

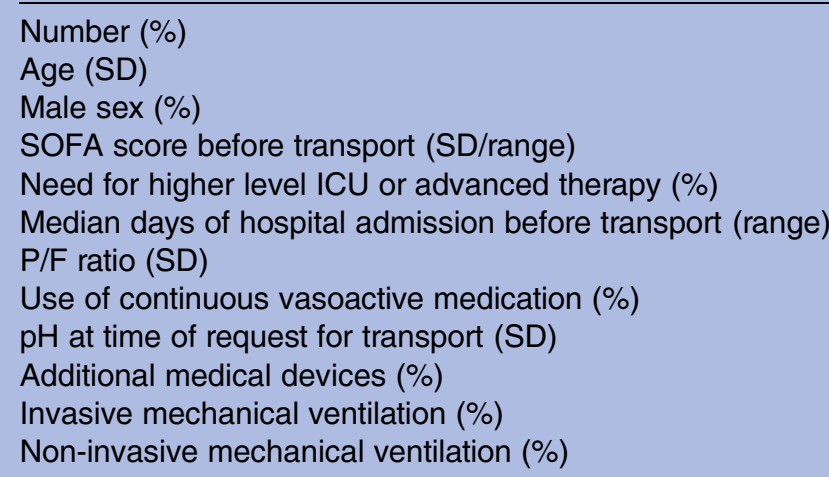

$344(100)$

$58(16.4)$

$236(68.6)$

$8.8(4.1 / 0-20)$

$218(63.4)$

$4(0-244)$

246 (113)

$152(44.2)$

$7.37(0.1)$

$22(6.4)$

$311(90.4)$

$6(1.7)$

\begin{tabular}{lccc}
\hline & V-V ECMO & V-A ECMO & All ECMO patients \\
\hline Number & 7 & 8 & 15 \\
Age (SD) & $40(15.9)$ & $52(8.6)$ & $46(13.4)$ \\
Male sex (\%) & $5(71.4)$ & $7(87.5)$ & $12(80.0)$ \\
SOFA score before transport (SD/range) & $14.0(1.5 / 13-17)$ & $13.8(2.4 / 11-17)$ & $13.9(2.0 / 11-17)$ \\
Days of hospital admission before transport (median/range) & $3(0-27)$ & $4(2-10)$ & $4(0-27)$ \\
P/F ratio (SD) & $92(41)$ & $240(87)$ & $177(106)$ \\
Use of continuous vasoactive medication (\%) & $6(85.7)$ & $6(75.0)$ & $12(80.0)$ \\
pH at time of request for transport (median/SD) & $7.28(0.1)$ & $7.45(0.1)$ & $7.37(0.12)$ \\
\hline
\end{tabular}

Vasoactive medication: norepinephrine, dobutamine, nitroglycerine.

Additional medical devices: V-V and V-A ECMO, IABP, NO.

Short-term cardiac assist devices: V-A ECMO or IABP.

ECMO, extracorporeal membrane oxygenation; IABP, intra-aortic balloon counter pulsation; $\mathrm{NO}$, nitric oxide; $\mathrm{P} / \mathrm{F}, \mathrm{PaO}_{2} / \mathrm{FiO}{ }_{2}$ ratio; $\mathrm{SOFA}$,

Sequential Organ Failure Assessment; V-A ECMO, veno-arterial ECMO; V-V ECMO, veno-venous ECMO.

The mean total transport time was $5.6 \mathrm{~h}$, which can be explained by the decentred position of the Maastricht Medical Centre and the absence of heart/lung transplantation and burn units in our region. Furthermore, we found that the 15 ECMO transports exceeded the mean transport time by nearly $4 \mathrm{~h}$ (table 2 ).

\section{Mortality}

In all, 14 patients died within $24 \mathrm{~h}$ after transport (4.1\%). We compared the group of patients who died with the group of patients who were alive $24 \mathrm{~h}$ after transport. Those patients who died within $24 \mathrm{~h}$ after transportation had a significantly higher SOFA score before transport

\section{Table 2 Transport characteristics and outcomes}

\begin{tabular}{|c|c|c|c|}
\hline \multicolumn{3}{|c|}{ SOFA score before transport of all patients (SD/range) } & $8.8(4.1 / 0-20)$ \\
\hline \multicolumn{3}{|c|}{ SOFA score before transport of patients being alive $24 \mathrm{~h}$ after transport (SD/range) } & $8.6(4.0 / 0-19)$ \\
\hline & $8.4(4.5 / 0-24)$ \\
\hline \multicolumn{3}{|c|}{ Patients deceased within $24 \mathrm{~h}$ after transport (\%) } & $14(4.1)$ \\
\hline \multicolumn{3}{|l|}{ Patients not being transported (\%) } & $2(0.6)$ \\
\hline \multicolumn{3}{|l|}{ Critical events (\%) } & $22(6.4)$ \\
\hline \multicolumn{3}{|l|}{ Total transport time in hours (SD/range) } & $5.6(1.9 / 1.5-11.5)$ \\
\hline & V-V ECMO & V-A ECMO & All ECMO patients \\
\hline SOFA score before transport (SD/range) & $14.0(1.5 / 13-17)$ & $13.8(2.4 / 11-17)$ & $13.9(2.0 / 11-17)$ \\
\hline SOFA score after transport (SD/range) & $15.0(4.2 / 12-24)$ & $12.2(2.1 / 10-16)$ & $13.7(3.6 / 10-24)$ \\
\hline Critical events (\%) & $0(0)$ & $2(25.0)$ & $2(13.3)$ \\
\hline Transport time in hours (SD/range) & $9.9(1.4 / 8.5-10.75)$ & $8.7(2.7 / 5.5-11.5)$ & $9.3(2.2 / 5.5-11.5)$ \\
\hline Patients deceased within $24 \mathrm{~h}$ after transport (\%) & $0(0)$ & $2(25.0)$ & $2(13.3)$ \\
\hline
\end{tabular}


(12.3 vs 8.6, $\mathrm{p}<0.001)$ indicating a higher severity of illness, were older, more often on vasoactive medication and more frequently had a cardiac diagnosis.

No differences were found in transport-related factors in terms of the number of critical events or total transport time (table 3 ).

To get more insight on the individual cases of those patients who died, we reviewed the patients' charts. Two patients died after arrival of the transport team in the referral hospital before transportation could be initiated because of massive bleeding and after massive aspiration.

Two patients with postcardiotomy left ventricular failure, transported with veno-arterial ECMO (V-A ECMO) and IABP, died in the perioperative period of surgical implantation of a left ventricular assist device. More than one-third of the patients (5/14) died within $24 \mathrm{~h}$ because the medical team decided to retain further therapy; three patients died due to refractory cardiogenic shock and two patients went into a pulseless electric activity secondary to multiorgan failure (table 4).

\section{DISCUSSION}

This study shows that interhospital transportation of critically ill patients with our MICU and a dedicated team can be performed without clinically relevant negative effects on the patient's condition and a critical event rate in line with current literature. The monitoring of severity of illness on the day of transport and $24 \mathrm{~h}$ after transport was introduced as a new parameter that can be used to detect transport-related effects on the patients' condition. The patients who died within $24 \mathrm{~h}$ after transportation had a higher severity of illness, were older, more often on vasoactive medication and most had a cardiac diagnosis.

Within the ongoing discussion concerning concentration of healthcare facilities, it is to be expected that qualified transport of critically ill patients will become a key factor of success in future intensive care medicine development. ${ }^{14-17}$ In this context, it seems to be of utmost importance not only to have qualified interhospital transportation systems, but also to develop practical and efficient tools that help to decide which individual patient will benefit from transportation to another hospital without undergoing major transportation risk. In 5 of the 14 patients who died within $24 \mathrm{~h}$ after transport in our population, further aggressive treatment was withheld in the accepting ICU. Retrospectively, it is questionable whether all these patients should have been transported, which emphasises the need for valid pretransport triage criteria.

In 2012, Barratt et $a l^{18}$ concluded, in a propensitymatched cohort analysis with more than 300000 patients, that there was no statistical significant difference in hospital mortality for the 759 patients undergoing a non-clinical interhospital critical care transfer, but that a level of harm, that may be considered as clinically relevant, cannot be ruled out.

Table 3 Characteristics of patients alive and deceased within $24 \mathrm{~h}$ after transport

\begin{tabular}{|c|c|c|c|}
\hline & $\begin{array}{l}\text { Patients alive } \\
24 \mathrm{~h} \text { after transport } \\
(\mathrm{n}=330)\end{array}$ & $\begin{array}{l}\text { Patients deceased } \\
\text { within } 24 \text { h after } \\
\text { transport }(n=14)\end{array}$ & p Value \\
\hline Age (SD) & $58(16.6)$ & $68(7.5)$ & $<0.001$ \\
\hline Male sex $(\%)$ & $227(68.5)$ & $9(64.3)$ & 0.722 \\
\hline SOFA score before transport (SD/range) & $8.6(4 / 0-19)$ & $12.3(3.5 / 9-20)$ & $<0.001$ \\
\hline Need for higher level ICU or advanced therapy (\%) & $206(62.4)$ & $12(85.7)$ & 0.076 \\
\hline Critical events (\%) & $21(6.4)$ & $1(7.1)$ & 0.611 \\
\hline Total transport time in hours (SD/range) & $5.6(1.9 / 1.5-11.5)$ & $5.5(1.7 / 4-8.5)$ & 0.850 \\
\hline Median days of hospital admission before transport (range) & $4(0-244)$ & $4(0-19)$ & $0.072^{*}$ \\
\hline $\mathrm{P} / \mathrm{F}$ ratio $(\mathrm{SD})$ & $249(113)$ & $192(96)$ & 0.064 \\
\hline Use of continuous vasoactive medication (\%) & $142(43.0)$ & $10(71.3)$ & 0.036 \\
\hline $\mathrm{pH}$ at time of request for transport (SD) & $7.38(0.09)$ & $7.23(0.18)$ & 0.011 \\
\hline Cardiac diagnosis $(\%)$ & $75(22.7)$ & $9(64.3)$ & 0.001 \\
\hline Additional medical devices (\%) & $19(5.8)$ & $3(21.4)$ & 0.052 \\
\hline Short-term cardiac assist devices (\%) & $11(3.3)$ & $3(21.4)$ & 0.015 \\
\hline Invasive mechanical ventilation (\%) & $298(90.3)$ & $13(92.9)$ & $>0.999$ \\
\hline Non-invasive ventilation (\%) & $5(1.5)$ & $1(7.1)$ & 0.222 \\
\hline Oxygen supply nasal or mask (\%) & $27(8.2)$ & $0(0)$ & 0.613 \\
\hline
\end{tabular}

*Mann-Whitney U test.

Total transport time: departure MICU team from our unit until return of the team plus time for updating the trolley.

Vasoactive medication: norepinephrine, dobutamine, nitroglycerine.

Cardiac diagnosis: CPR, severe valve dysfunction, cardiogenic shock, myocardial infarction.

Additional medical devices: V-V and V-A ECMO, IABP, NO.

Short-term cardiac assist devices: $\mathrm{V}-\mathrm{A}$ ECMO or IABP.

CPR, cardiopulmonary resuscitation; ECMO, extracorporeal membrane oxygenation; IABP, intra-aortic balloon counter pulsation; ICU, intensive care unit; MICU, mobile intensive care unit; $\mathrm{NO}$, nitric oxide; $\mathrm{P} / \mathrm{F}, \mathrm{PaO}_{2} / \mathrm{FiO}_{2}$ ratio; SOFA, Sequential Organ Failure Assessment; V-A ECMO, veno-arterial ECMO; V-V ECMO, veno-venous ECMO. 
Table 4 Patient characteristics and cause of death of patients deceased within $24 \mathrm{~h}$ after transport

\begin{tabular}{|c|c|c|c|c|c|}
\hline $\mathbf{n}$ & $\begin{array}{l}\text { Major diagnosis } \\
\text { before transport }\end{array}$ & $\begin{array}{l}\text { SOFA } \\
\text { score }\end{array}$ & $\begin{array}{l}\text { Reason for } \\
\text { transfer }\end{array}$ & Special remarks & Cause of death \\
\hline 1 & $\begin{array}{l}\text { Cardiogenic shock, } \\
\text { severe aortic valve } \\
\text { stenosis }\end{array}$ & 13 & $\begin{array}{l}\text { Further treatment } \\
\text { in EC }\end{array}$ & & $\begin{array}{l}\text { Refractory cardiogenic shock, no } \\
\text { surgical options }\end{array}$ \\
\hline 2 & $\begin{array}{l}\text { Postcardiotomy left } \\
\text { ventricular failure }\end{array}$ & 17 & $\begin{array}{l}\text { Further treatment } \\
\text { in EC }\end{array}$ & $\begin{array}{l}\text { Transport with V-A ECMO } \\
\text { and IABP }\end{array}$ & Perioperative death (LVAD) \\
\hline 3 & $\begin{array}{l}\text { Cardiac arrest caused } \\
\text { by } \mathrm{Ml}\end{array}$ & 12 & $\begin{array}{l}\text { No ICU beds } \\
\text { available at } \\
\text { tertiary centre }\end{array}$ & & $\begin{array}{l}\text { Withdrawal of therapy because of } \\
\text { persistent cardiogenic shock and } \\
\text { anoxic encephalopathy }\end{array}$ \\
\hline 4 & $\begin{array}{l}\text { Hypovolemic shock } \\
\text { caused by bleeding } \\
\text { pancreatic tumour }\end{array}$ & 11 & $\begin{array}{l}\text { Further treatment } \\
\text { in EC }\end{array}$ & & $\begin{array}{l}\text { During transfer from patient bed to } \\
\text { transport trolley a massive } \\
\text { rebleeding occurred, after } \\
\text { discussion with intensivist from } \\
\text { local hospital transport was } \\
\text { cancelled }\end{array}$ \\
\hline 5 & $\begin{array}{l}\text { Cardiogenic shock } \\
\text { after MI and CPR }\end{array}$ & 12 & $\begin{array}{l}\text { Further treatment } \\
\text { in EC }\end{array}$ & $\begin{array}{l}\text { IABP (placed by MICU } \\
\text { team) }\end{array}$ & $\begin{array}{l}\text { Withdrawal of therapy because of } \\
\text { MOF and poor preadmission } \\
\text { performance }\end{array}$ \\
\hline 6 & $\begin{array}{l}\text { Cardiogenic shock } \\
\text { after MI with RF }\end{array}$ & 7 & $\begin{array}{l}\text { Further treatment } \\
\text { in EC }\end{array}$ & Transport on NIV & Refractory cardiogenic shock \\
\hline 7 & $\begin{array}{l}\text { MOF/severe liver } \\
\text { failure }\end{array}$ & 20 & $\begin{array}{l}\text { Further treatment } \\
\text { in EC }\end{array}$ & & PEA due to MOF \\
\hline 8 & CPR due to VF & 10 & $\begin{array}{l}\text { No ICU beds } \\
\text { available at local } \\
\text { hospital }\end{array}$ & & $\begin{array}{l}\text { Withdrawal of therapy because of } \\
\text { poor neurological prognosis and } \\
\text { poor preadmission performance }\end{array}$ \\
\hline 9 & $\begin{array}{l}\text { Severe mitral valve } \\
\text { insufficiency }\end{array}$ & 14 & $\begin{array}{l}\text { Further treatment } \\
\text { in EC }\end{array}$ & & $\begin{array}{l}\text { Refractory cardiogenic shock, no } \\
\text { surgical options }\end{array}$ \\
\hline 10 & $\begin{array}{l}\text { Postcardiotomy left } \\
\text { ventricular failure }\end{array}$ & 15 & $\begin{array}{l}\text { Further treatment } \\
\text { in EC }\end{array}$ & $\begin{array}{l}\text { Transport with V-A ECMO } \\
\text { and IABP }\end{array}$ & Perioperative death (LVAD) \\
\hline 11 & $\begin{array}{l}\text { CPR due to } \\
\text { hypoxaemia }\end{array}$ & 8 & $\begin{array}{l}\text { No ICU beds } \\
\text { available at local } \\
\text { hospital }\end{array}$ & 10 min delay before BLS & $\begin{array}{l}\text { Withdrawal of therapy because of } \\
\text { poor neurological status with } \\
\text { brainstem dysfunction }\end{array}$ \\
\hline 12 & Traumatic brain injury & 15 & $\begin{array}{l}\text { Further treatment } \\
\text { in trauma centre }\end{array}$ & & $\begin{array}{l}\text { Withdrawal of therapy because of } \\
\text { severe traumatic brain injury with } \\
\text { brainstem dysfunction, no surgical } \\
\text { options }\end{array}$ \\
\hline 13 & $\begin{array}{l}\text { Respiratory failure after } \\
\text { aspiration MRSA+ }\end{array}$ & 12 & $\begin{array}{l}\text { No isolation bed } \\
\text { available at local } \\
\text { ICU (MRSA } \\
\text { patient) }\end{array}$ & $\begin{array}{l}6 \mathrm{~h} \text { treatment at isolation } \\
\text { box on general ward at } \\
\text { local hospital with MICU } \\
\text { equipment by MICU/local } \\
\text { ICU team }\end{array}$ & $\begin{array}{l}\text { Unless maximum therapy further } \\
\text { deterioration occurred, patient died } \\
\text { due to refractory hypoxaemia }\end{array}$ \\
\hline 14 & $\begin{array}{l}\text { MOF due to legionella } \\
\text { pneumonia }\end{array}$ & 17 & $\begin{array}{l}\text { Further treatment } \\
\text { in EC }\end{array}$ & & PEA due to MOF \\
\hline
\end{tabular}

So, do we need specialised retrieval teams and what parameters should we use to determine the quality of a transport facility?

Belway et $a l^{19}$ concluded in a systematic review in 2006, that current data are insufficient to determine whether the use of specialist transport personnel improves patient outcome. Moreover, also in 2006, Fan $e t a l^{20}$ concluded in a systematic review that insufficient data exist to draw firm conclusions regarding the mortality, morbidity or risk factors associated with the interfacility transport.
In general, proxy parameters, critical event rate, number of physiological parameters beyond a predefined threshold or short-term mortality, are used and studies using these parameters suggest that specialised retrieval teams perform better. ${ }^{8}{ }^{9} 2122$ In this study, short-term mortality and short-term morbidity was analysed by monitoring SOFA scores directly, before and $24 \mathrm{~h}$ after transport; this is a potentially practical parameter. Nevertheless, we agree with the conclusions of Fan et al, and doubt whether the aforementioned parameters sufficiently reflect quality of interhospital transport. 
A lot of non-transport-related factors interfere with short-term morbidity and certainly with short-term mortality. ${ }^{23-25}$ However, what does a decrease in oxygen saturation below a certain threshold mean if we do not see this in the context of the severity of the patient's lung failure?

The incidence of critical events during transportation of patients varies in the literature. It is important, however, to emphasise that there is no clear standard definition for adverse events during transportation. Fanara $e t a l^{1}$ described a critical event rate for intrahospital transport of up to $68 \%$, with serious adverse events ranging between $4.2 \%$ and $8.9 \%$. Wiegersma et a ${ }^{9}$ report a critical event rate for interhospital transport of $12.5 \%$ due to technical problems, but without the need for immediate intervention. Uusaro et $a l^{26}$ reported no major medical or technical complications during interhospital transport of severely hypoxic patients. An analysis of 191 mechanical-ventilated patients undergoing rotary wing transport showed that $22 \%$ of the patients experienced a minor event. ${ }^{27}$ In our study, a critical event rate of $6.4 \%$ was found which appears in line with current literature.

The question rises as to whether the $4.1 \% 24 \mathrm{~h}$ mortality in the present study was influenced by transport-related factors. The pretransport data of these non-survivors as compared with the survivors showed higher SOFA scores, lower $\mathrm{pH}$, higher age, the frequent use of vasoactive/inotropic medication, more cardiac diagnoses and more often transport with short-term cardiac assist devices. Since there were no differences between the two groups of patients in the number of critical events or other transport-related parameters, but a significant difference concerning severity of illness, we conclude that mainly the pre-existing clinical status was responsible for the difference in mortality between the two groups, and that the contribution of the transport per se was limited. Certainly, the low number of patients in the non-survivor group makes it difficult to draw meaningful conclusions. Moreover, knowledge on the physiological impact of transportation on critically ill patients is scarce and possible factors that may contribute are yet unknown.

There are several limitations to the present paper. This study is a descriptive analysis of a single-centre database with a limited number of patients and with only one post-transport data set (SOFA score) $24 \mathrm{~h}$ after MICU transport. Owing to the single-centre character of the study in a certain region of the Netherlands, selection bias cannot be ruled out. Moreover, transportation was carried out by a dedicated, well-trained retrieval team in a fully equipped ambulance which might not be available in many other centres or countries, and limits generalisability.

Although these data are not specific enough to answer the question of which patient will benefit from being transported and how to monitor quality of interhospital transport, our results do suggest that there are certain patient characteristics indicating a high risk for short-term mortality and that measuring short-term outcome appears useful to determine whether there is a negative transport-related effect on the patients' clinical condition.

\section{CONCLUSION}

Interhospital transport of intensive care patients performed by a specialised retrieval team with advanced ICU equipment in the South East of the Netherlands has no negative effect on short-term (24 h) outcomes. Short-term $(24 \mathrm{~h})$ mortality after MICU transport appears mainly influenced by the natural course of critical illness and decisions to retain further aggressive therapy in individual patients. More research is required, data on stratification of patients who will benefit from transportation and the development of a system that enables evaluation of the quality of transportation seem most urgent.

Contributors US is main author, acquired the data and drafted the manuscript. DCJJB participated in the design of the study and has been involved in drafting and revising the manuscript. BW participated in the design of the study, performed statistical analysis and has been involved in revising the manuscript. PMHJR participated in the design of the study, in revising the manuscript and has given final approval.

Funding This research received no specific grant from any funding agency in the public, commercial or not-for-profit sectors.

\section{Competing interests None declared}

Ethics approval The study was approved by the Ethics Committee of the Maastricht University Medical Centre+, which waived the need for written informed consent because of the observational design and as the study did not impact on patient management.

Provenance and peer review Not commissioned; externally peer reviewed.

Data sharing statement No additional data are available.

Open Access This is an Open Access article distributed in accordance with the Creative Commons Attribution Non Commercial (CC BY-NC 4.0) license, which permits others to distribute, remix, adapt, build upon this work noncommercially, and license their derivative works on different terms, provided the original work is properly cited and the use is non-commercial. See: http:// creativecommons.org/licenses/by-nc/4.0/

\section{REFERENCES}

1. Fanara B, Manzon C, Barbout O, et al. Recommendations for the intra-hospital transport of critically ill patients. Crit Care 2010;14:R87.

2. Lahner D, Nikolic A, Marhofer P, et al. Incidence of complications in intrahospital transport of critically ill patients-experience in an Austrian university hospital. Wien Klin Wochenschr 2007;119:412-16

3. Papson JP, Russell KL, Taylor DM. Unexpected events during the intrahospital transport of critically ill patients. Acad Emerg Med 2007;14:574-7.

4. Beckmann U, Gillies DM, Berenholtz SM, et al. Incidents relating to the intra-hospital transfer of critically ill patients. An analysis of the reports submitted to the Australian Incident Monitoring Study in Intensive Care. Intensive Care Med 2004;30:1579-85.

5. Warren J, Fromm RE, Orr R, et al. Guidelines for the inter- and intrahospital transport of critically ill patients. Crit Care Med 2004;32:256-62.

6. Ramnarayan P, Thiru K, Parslow RC, et al. Effect of specialist retrieval teams on outcomes in children admitted to paediatric intensive care units in England and Wales: a retrospective cohort study. Lancet 2010;376:698-704.

7. Vos GD, Nissen AC, Nieman FH, et al. Comparison of interhospital pediatric intensive care transport accompanied by a referring 
specialist or a specialist retrieval team. Intensive Care Med 2004;30:302-8.

8. Bellingan $\mathrm{G}$, Olivier $\mathrm{T}$, Batson $\mathrm{S}$, et al. Comparison of a specialist retrieval team with current United Kingdom practice for the transport of critically ill patients. Intensive Care Med 2000;26:740-4.

9. Wiegersma JS, Droogh JM, Zijstra JG, et al. Quality of interhospital transport of the critically ill: impact of a Mobile Intensive Care Unit with a specialized retrieval team. Crit Care 2011;15:R75.

10. Gebremichael M, Borg U, Habashi N, et al. Interhospital transport of the extremely ill patient: the mobile intensive care unit. Crit Care Med 2000;28:79-85.

11. Inspectie voor de Gezondheidszorg, Ministerie van Volksgezondheid, Welzijn en Sport, Netherlands Intensieve Zorgen. Capaciteit-en transportproblemen bij IC in kaart gebracht. 2005. http://www.igz.nl/zoeken/document.aspx?doc=Intensieve \pm Zorgen +Capaciteit-+en+transportproblemen+bij+lC+in+kaart + gebracht $\&$ docid $=540$

12. Ministry of Public Health. Temporary guideline coordinating MICUcenters and MICU-transfer. 23 Oct 2007. http://www. rijksoverheid.nl/documenten-en-publicaties/kamerstukken/2007/11/ 05/tijdelijke-regelingmicu-transport.html

13. Ferreira FL, Bota DP, Bross A, et al. Serial evaluation of the SOFA score to predict outcome in critically ill patients. JAMA 2001;286:1754-8.

14. Kahn JM, Linde-Zwirble WT, Wunsch $\mathrm{H}$, et al. Potential value of regionalized intensive care for mechanically ventilated medical patients. Am J Respir Crit Care Med 2008;177:285-91.

15. Nguyen YL, Kahn JM, Angus DC. Reorganizing adult critical care delivery. The role of regionalization, telemedicine, and community outreach. Am J Respir Crit Care Med 2010;181:1164-9.

16. Kahn JM, Branas CC, Schwab W, et al. Regionalization of medical critical care: what can we learn from the trauma experience? Crit Care Med 2008;36:3085-8.
17. Singh JM, Mac Donald RD. Pro/con debate: do the benefits of regionalized critical care delivery outweigh the risks of interfacility patient transport? Crit Care 2009;13:219.

18. Barratt $\mathrm{H}$, Harrison DA, Rowan $\mathrm{KM}$, et al. Effect of non-clinical inter-hospital critical care unit to unit transfer of critically ill patients: a propensity-matched cohort analysis. Crit Care 2012;16:R179.

19. Belway D, Henderson W, Keenan SP, et al. Do specialist transport personnel improve hospital outcome in critically ill patients transferred to higher centers? A systematic review. J Crit Care 2006;21:8-18.

20. Fan E, Mac Donald RD, Adhikari NKJ, et al. Outcomes of interfacility critical care adult patient transport: a systematic review. Crit Care 2006;10:R6

21. Ligtenberg JJM, Arnold LG, Stienstra Y, et al. Quality of interhospital transport of critically ill patients: a prospective audit. Crit Care 2005;9:R446-51.

22. Ramnarayan P. Measuring the performance of an inter-hospital transport service. Arch Dis Child 2009;94:414-16.

23. Combes A, Luyt CE, Trouillet JL, et al. Adverse effect on a referral intensive care unit's performance of accepting patients transferred from another intensive care unit. Crit Care Med 2005;33:705-10.

24. Durairaj L, Will JG, Torner JC, et al. Prognostic factors for mortality following interhospital transfers to the medical intensive care unit of a tertiary referral center. Crit Care Med 2003;31:1981-6.

25. Rosenberg AL, Hofer TP, Strachan C, et al. Accepting critically il transfer patients: adverse effect on a referral center's outcome and benchmark measures. Ann Intern Med 2003;138:882-90.

26. Uusaro A, Parviainen I, Takala J, et al. Safe long-distance interhospital ground transfer of critically ill patients with acute severe unstable respiratory and circulatory failure. Intensive Care Med 2002;28:1122-5.

27. Seymour CW, Kahn JM, Schwab CW, et al. Adverse events during rotary-wing transport of mechanically ventilated patients: a retrospective cohort study. Crit Care 2008;12:R71. 